\title{
Resveratrol induces apoptosis in SGC-7901 gastric cancer cells
}

\author{
XIAOXUE WU ${ }^{1,2}$, YUNDAN XU $^{2}$, BIRAN ZHU ${ }^{2}$, QIANG LIU ${ }^{2}$, QUNFENG YAO $^{1 *}$ and GANG ZHAO ${ }^{2 *}$ \\ ${ }^{1}$ Department of Biotechnology, School of Laboratory Medicine; ${ }^{2}$ Department of Medical Biology, School of \\ Basic Medical Sciences, Hubei University of Chinese Medicine, Wuhan, Hubei 430065, P.R. China
}

Received October 27, 2017; Accepted May 31, 2018

DOI: $10.3892 / \mathrm{ol} .2018 .9045$

\begin{abstract}
The aim of the present study was to investigate the effect of resveratrol on apoptosis in SGC-7901 gastric cancer cells and its molecular mechanisms of action. Following resveratrol treatment, the inhibition rate of SGC-7901 cells was determined using an MTT assay. The morphological changes in apoptosis were observed by fluorescence microscopy based on acridine orange/ethidium bromide double staining. Furthermore, cell cycle and apoptosis were detected using flow cytometry, and the expression levels of nuclear factor $\kappa \mathrm{B}(\mathrm{NF}-\kappa \mathrm{B})$ as well as apoptosis-associated proteins [B-cell lymphoma 2 (Bcl-2), Bcl-2-associated X protein (Bax), cleaved caspase-3 and cleaved caspase-8] were analyzed by western blotting. The results of the present study indicated that resveratrol was able to significantly inhibit the viability of SGC-7901 cells in a dose- and time-dependent manner. When treated with $200 \mu \mathrm{M}$ resveratrol, the inhibition rate of SGC-7901 cells reached $\sim 50 \%$. In the presence of resveratrol, the proportion of apoptotic cells was also increased in a dose-dependent manner. Flow cytometry revealed that resveratrol induced S-phase arrest of SGC-7901 cells. When treated with 50, 200 and $400 \mu \mathrm{M}$ resveratrol, the proportions of SGC-7901 cells in the S-phase were respectively increased to $33.8 \pm 2.42,60.01 \pm 2.43$ and $56.05 \pm 2.67 \%$, compared with $25.62 \pm 3.29 \%$ for the control group cells in S-phase. Additionally, the levels of the pro-apoptotic proteins Bax, cleaved caspase- 3 and cleaved caspase- 8 were upregulated in a dose-dependent manner, whereas the level of the anti-apoptotic protein $\mathrm{Bcl}-2$ was downregulated dose-dependently.
\end{abstract}

Correspondence to: Professor Gang Zhao, Department of Medical Biology, School of Basic Medical Sciences, Hubei University of Chinese Medicine, 1 Huangjiahu West Road, Hongshan, Wuhan, Hubei 430065, P.R. China

E-mail: zgcc66@163.com

Professor Qunfeng Yao, Department of Biotechnology, School of Laboratory Medicine, Hubei University of Chinese Medicine, 1 Huangjiahu West Road, Wuhan, Hubei 430065, P.R. China

E-mail: hbzyyqf@163.com

${ }^{*}$ Contributed equally

Key words: resveratrol, gastric cancer, SGC-7901 cells, apoptosis, nuclear factor- $\kappa \mathrm{B}$
Importantly, the activation of $\mathrm{NF}-\kappa \mathrm{B}$ (p65) was evidently decreased following treatment with resveratrol compared with in the control group. In conclusion, the results of the present study revealed that resveratrol was able to inhibit viability and induce apoptosis in SGC-7901 cells by suppressing NF- $\kappa \mathrm{B}$ activation. Therefore, resveratrol may be considered as a potential drug candidate for the treatment of gastric cancer.

\section{Introduction}

Gastric cancer is a common malignancy with high morbidity and mortality in men and women (1). The 5-year relative survival rate of patients with gastric cancer is only $20 \%$ worldwide (2). In 2012, 952,000 individuals were diagnosed with gastric cancer and 723,000 succumbed to the disease (3). The conventional method of treating gastric cancer is surgery, and, when accompanied by adjuvant chemotherapy and radiotherapy, the prognosis of patients with gastric cancer may be markedly improved (4). Chemotherapy is a successful method of decreasing pain and prolonging the life expectancy of patients with gastric cancer (5). However, owing to side effects and drug resistance, the clinical efficacy of chemotherapeutic agents is limited $(6,7)$. Owing to a small number of side effects and the wide range of targets of plant-derived components, a number of previous studies have focused on the function of plant-derived agents in antitumor treatment (8-10).

Resveratrol (3,4,5-trihydroxystilbene) is a natural phytoalexin product, and is widely present in a variety of plants, including grapes, berries and the Chinese medicine plant Polygonum cuspidatum (Japanese knotweed) (11). As an important component of red wine, resveratrol has long been hypothesized to exhibit cardioprotective effects, and it is well-known for its phytoestrogenic and antioxidant properties (12-15). In addition, previous studies have identified that resveratrol was able to prolong lifespan and resist cancer. For instance, feeding fish with resveratrol resulted in an increase in median and maximum lifespan by 33 and $27 \%$, respectively, compared with fish that were fed without resveratrol supplementation (16). Furthermore, injection of resveratrol into mice led to a significant inhibition of the proliferation of breast cancer stem cell-like cells by suppressing the Wnt/ $\beta$-catenin signaling pathway (17). Although these studies demonstrated the antitumor effect of resveratrol, the precise underlying molecular mechanisms remain unclear.

In the present study, the gastric cancer cell line SGC-7901 was used to investigate the effects and acting mechanisms of 
resveratrol on cell viability and apoptosis. The results may provide an improved understanding of the effects of resveratrol in the treatment of gastric cancer.

\section{Materials and methods}

Chemicals and reagents. Resveratrol (Chemical Abstracts Service identifier, 501-36-0; purity $\geq 99 \%$ ), MTT, acridine orange (AO), ethidium bromide $(\mathrm{EB})$ and propidium iodide (PI) were purchased from Sigma-Aldrich; Merck KGaA (Darmstadt, Germany). Resveratrol was dissolved in dimethyl sulfoxide (DMSO) to form a $100 \mathrm{mM}$ stock solution. MTT was dissolved in PBS to form a $5 \mathrm{mg} / \mathrm{ml}$ working solution. RPMI-1640 medium was purchased from HyClone; GE Healthcare (Chicago, IL, USA) and fetal bovine serum (FBS) was purchased from Hangzhou Sijiqing Biological Engineering Materials Co., Ltd. (Hangzhou, China). All other chemicals and reagents used in the present study were of analytical grade.

Cell culture. SGC-7901 cells were purchased from the China Center for Type Culture Collection (Wuhan, China) and cultured in RPMI-1640 medium supplemented with $10 \%$ FBS and antibiotics $(100 \mathrm{U} / \mathrm{ml}$ streptomycin and $100 \mathrm{U} / \mathrm{ml}$ penicillin) in $25-\mathrm{cm}^{2}$ culture flasks at $37^{\circ} \mathrm{C}$ in a humidified atmosphere containing 5\% $\mathrm{CO}_{2}$. When the SGC-7901 cells reached exponential growth phase, the cells were subcultured and the experiments were performed on the subcultured cells.

MTT assay. The anti-proliferative effect of resveratrol against SGC-7901 cells was determined using the colorimetric MTT assay as described previously (18). The SGC-7901 cells were seeded on 96-well culture plates with RPMI-1640 medium at a density of $1 \times 10^{4}$ cells $/ \mathrm{ml}$. Following incubation for $24 \mathrm{~h}$ at $37^{\circ} \mathrm{C}$, the cells were treated with different concentrations of resveratrol $(0,10,50,100,200$ and $400 \mu \mathrm{M})$ for 24,36 and $48 \mathrm{~h}$. Subsequently, $10 \mu \mathrm{l}$ MTT $(5 \mathrm{mg} / \mathrm{ml})$ was separately added to each well, and the cells were cultured at $37^{\circ} \mathrm{C}$ for an additional $3 \mathrm{~h}$. Finally, $150 \mu \mathrm{l}$ DMSO was separately added to each well and the optical density (OD) was determined at $490 \mathrm{~nm}$ using a microplate reader (Bio-Rad Laboratories, Inc., Hercules, CA, USA). The inhibition rate of resveratrol against the SGC-7901 cells was determined using the equation: Inhibition rate $(\%)=\left(\mathrm{OD}_{\text {control }}-\mathrm{OD}_{\text {treatment }}\right) / \mathrm{OD}_{\text {control }} \times 100$.

AO/EB dual staining assay. The apoptosis of SGC-7901 cells induced by resveratrol was examined using an $\mathrm{AO} / \mathrm{EB}$ dual-fluorescence staining assay as described previously (19). Sterile round coverslips were placed on the bottom of the wells of a 12-well plate onto which the SGC-7901 cells were seeded with RPMI-1640 medium at a density of $1 \times 10^{4}$ cells $/ \mathrm{ml}$. After $24 \mathrm{~h}$ of incubation at $37^{\circ} \mathrm{C}$, the cells were treated with different concentrations of resveratrol $(0,50,200$ and $400 \mu \mathrm{M}$ ) for $24 \mathrm{~h}$. Subsequently, the round coverslips were removed. Dual-fluorescence staining solution $(10 \mu \mathrm{l})$ containing $100 \mu \mathrm{g} / \mathrm{ml} \mathrm{AO}$ and $100 \mu \mathrm{g} / \mathrm{ml}$ EB was added to each suspension prior to being covered with a coverslip. The morphology of cells was examined in each sample within 20 min using a fluorescence microscope (Nikon 80i; Nikon Corporation, Tokyo, Japan).
Apoptosis assay. Cell apoptosis was determined using flow cytometry following treatment as described previously (20). SGC-7901 cells were seeded in 6-well culture plates with RPMI-1640 medium and left to attach overnight at $37^{\circ} \mathrm{C}$ at a density of $1 \times 10^{4}$ cells $/ \mathrm{ml}$. Following treatment with resveratrol $(0,50,200$ and $400 \mu \mathrm{M})$ for $24 \mathrm{~h}$, the cells were harvested and prepared as cell suspensions. Adherent cells were digested with EDTA-free trypsin and washed three times with ice-cold PBS. Subsequently, the cells $\left(1 \times 10^{6}\right.$ cells $\left./ \mathrm{ml}\right)$ were resuspended in $200 \mu \mathrm{l}$ staining buffer. Annexin V-fluorescein isothiocyanate staining solution $(2 \mu \mathrm{l})$ was then added to the cell suspension. The mixture was gently mixed and incubated in the dark at $2-8^{\circ} \mathrm{C}$ for $15 \mathrm{~min}$. Subsequently, $4 \mu 1$ PI staining solution was added to the cell suspension. The mixture was mixed and incubated in the dark at $2-8^{\circ} \mathrm{C}$ for $5 \mathrm{~min}$. The apoptotic cells were quantified immediately using a flow cytometer (BD Accuri C6; BD Biosciences, Franklin Lakes, NJ, USA) and the results were analyzed using FlowJo software (version 7.6; FlowJo LLC, Ashland, OR, USA).

Cell cycle assay. Cell cycle distribution was detected using a flow cytometer following drug treatment as described previously (21). SGC-7901 cells were seeded in 6-well culture plates at a density of $1 \times 10^{4}$ cells $/ \mathrm{ml}$ with RPMI-1640 medium and left to attach overnight at $37^{\circ} \mathrm{C}$. Following treatment with resveratrol $(0,50,200$ and $400 \mu \mathrm{M})$, cells were incubated further with the compounds for $24 \mathrm{~h}$ at $37^{\circ} \mathrm{C}$ before being harvested, washed twice with PBS and resuspended in $2 \mathrm{ml}$ ice-cold PBS. The cells were fixed with cold $\left(-20^{\circ} \mathrm{C}\right) 70 \%$ ethanol overnight at $4^{\circ} \mathrm{C}$. Following three PBS washes, the cells were resuspended in $2 \mathrm{ml} \mathrm{PI} / \mathrm{RNase}$ staining solution and incubated for $1 \mathrm{~h}$ at $4^{\circ} \mathrm{C}$. Cells were quantified immediately using a flow cytometer (BD Accuri C6) and the results were analyzed using ModFitLT ${ }^{\mathrm{TM}}$ software (version 5.1; Verity Software House, Inc., Topsham, ME, USA). The PI fluorescence signal at FL2-A peak versus counts was used to determine cell cycle distribution.

Western blot analysis. Following treatment, proteins in SGC-7901 cells were extracted as described previously (22). Following treatment with resveratrol $(0,50,200$ and $400 \mu \mathrm{M})$ for $24 \mathrm{~h}$, total protein was extracted with cell lysis buffer (Beyotime Institute of Biotechnology, Haimen, China), centrifuged at $13,4000 \mathrm{xg}$ for $10 \mathrm{~min}$ at $4^{\circ} \mathrm{C}$. Nuclear and cytosolic proteins were extracted using a Nuclear and Cytoplasmic Protein Extraction kit (Applygen Technologies, Inc., Beijing, China), according to the manufacturer's protocol. The cell lysate was mixed with $2 \mathrm{mM} \mathrm{Na}_{3} \mathrm{VO}_{4}$, as a phosphorylation protective agent. Protein concentrations were determined using a Bicinchoninic Acid Protein Assay kit (Wuhan Boster Biological Technology, Ltd., Wuhan, China), according to the manufacturer's protocol. Total protein $(40 \mu \mathrm{g})$ was separated using SDS-PAGE (12\% gel) and transferred onto a nitrocellulose membrane (EMD Millipore, Billerica, MA, USA). Following blocking with Tris-buffered saline containing 1\% Tween-20 (TBST) and 5\% fat-free milk powder, the membrane was incubated with primary antibodies against $\beta$-actin (cat. no. bs-0061R, 1:1,000; BIOSS, Beijing, China), histone H3 (cat. no. bs-0349R, 1:1,000; BIOSS), B-cell lymphoma 2 (Bcl-2; cat. no. bs-20351R, 1:200; BIOSS), Bcl-2-associated X protein (Bax; cat. no. bs-0127R, 1:200; 
A

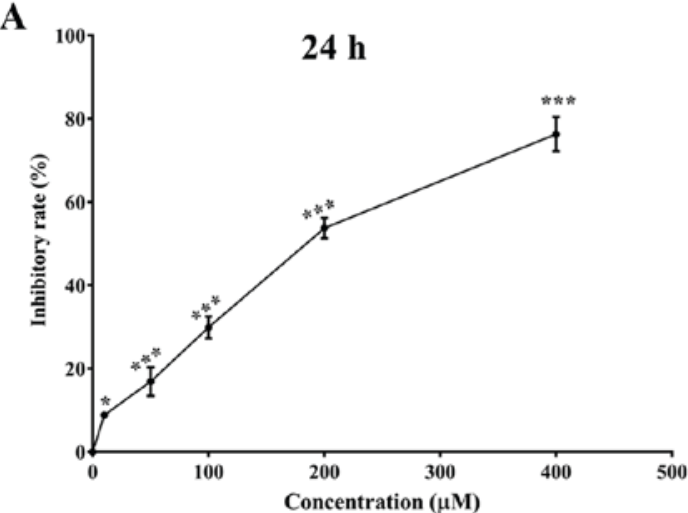

C

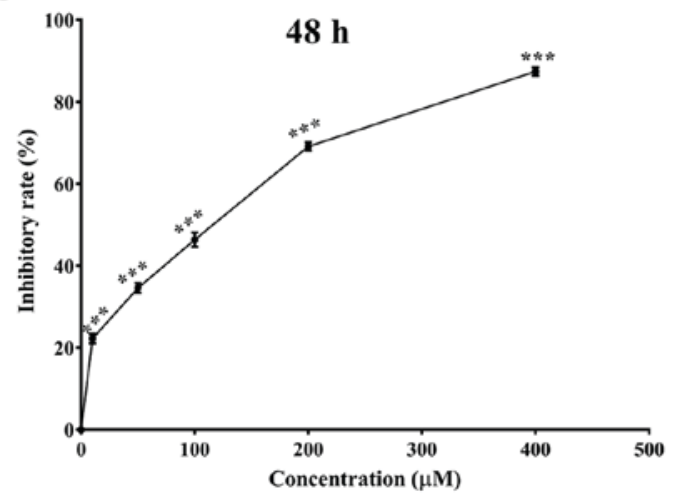

B

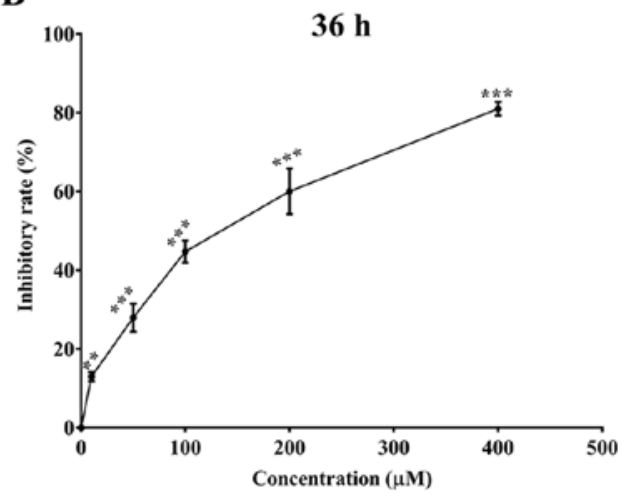

D

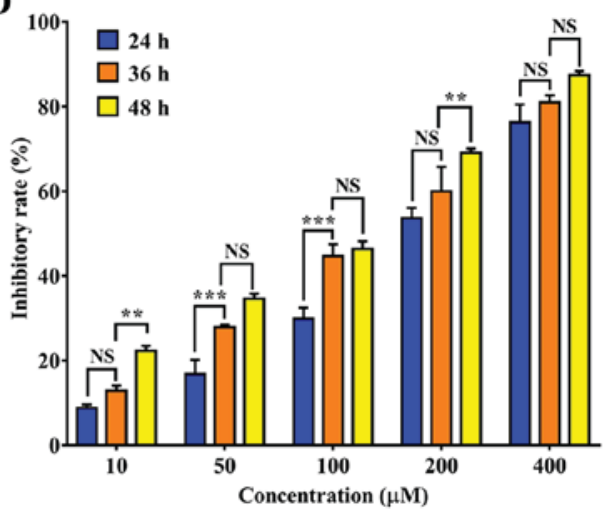

Figure 1. Resveratrol inhibits the viability of SGC-7901 cells. The cell viability inhibitory rate was determined using an MTT assay. SGC-7901 cells were treated with $0,10,50,100,200$ and $400 \mu \mathrm{M}$ resveratrol for (A) 24, (B) 36 and (C) $48 \mathrm{~h}$. (D) SGC-7901 cells were treated with 0 , $10,50,100,200$ and $400 \mu \mathrm{M}$ resveratrol for 24,36 and $48 \mathrm{~h}$, and the inhibitory rate at each concentration at different times was compared. Results are presented as the mean \pm standard deviation ( $n=3) .{ }^{*} \mathrm{P}<0.05,{ }^{* *} \mathrm{P}<0.01$ and ${ }^{* * *} \mathrm{P}<0.001$ vs. control group.

BIOSS), cleaved caspase-3 (cat. no. BA2885-2, 1:200; Wuhan Boster Biological Technology, Ltd.), cleaved caspase-8 (cat. no. BA3971, 1:200; Wuhan Boster Biological Technology, Ltd.), pro-caspase-3 (cat. no. BM3954, 1:200; Wuhan Boster Biological Technology, Ltd.), pro-caspase-8 (cat. no. BM4423, 1:200; Wuhan Boster Biological Technology, Ltd.), nuclear factor $\kappa \mathrm{B}(\mathrm{NF}-\kappa \mathrm{B})(\mathrm{p} 65)$ (cat. no. 10745-1-AP, 1:1,000; ProteinTech Group, Inc., Chicago, IL, USA) and phospho-NF-кB (p65) (cat. no. bs-0982R, 1:1,000; BIOSS) overnight at $4^{\circ} \mathrm{C}$. The membrane was then washed with TBST and incubated with the corresponding horseradish peroxidase-conjugated goat anti-rabbit secondary antibody (Santa Cruz Biotechnology, Inc., Dallas, TX, USA) in TBST for $2 \mathrm{~h}$ at room temperature. Following a further rinse, all proteins were detected using chemiluminescence reagent (ECL Plus reagent; Beyotime Institute of Biotechnology). The result was analyzed using Image $\mathrm{Lab}^{\mathrm{TM}}$ software (version 5.0; MCM DESIGN, Hillerød, Denmark). $\beta$-actin was used as a loading control for whole cell and cytoplasmic proteins. Histone H3 was used as an internal control for detection of nuclear proteins.

Statistical analysis. Each experiment was performed at least three times. Results are presented as the mean \pm standard deviation. The results were analyzed by one-way analysis of variance followed by a least significant difference post hoc test using SPSS (version 19.0; IBM Corp., Armonk, NY, USA). $\mathrm{P}<0.05$ was considered to indicate a statistically significant difference.

\section{Results}

Resveratrol inhibits the viability of SGC-7901 cells. SGC-7901 cells were treated with different concentrations of resveratrol for 24, 36 and $48 \mathrm{~h}$, respectively (Fig. 1A-C). Cell viability was analyzed by MTT assay. As presented in Fig. 1D, the inhibition of cell viability was significantly increased in SGC-7901 cells in response to resveratrol in a dose- and time-dependent manner compared with the control group $(0 \mu \mathrm{M}$ resveratrol $)(\mathrm{P}<0.05)$.

Resveratrol induces the apoptosis of SGC-7901 cells. SGC-7901 cells were treated with different doses of resveratrol for $24 \mathrm{~h}$, labeled using $\mathrm{AO} / \mathrm{EB}$ and examined using a fluorescence microscope (Fig. 2A). The staining of early-stage apoptotic cells was marked by crescent-shaped or granular yellow-green AO nuclear staining, and orange nuclear EB staining was asymmetrically localized in late-stage apoptotic cells. In the control group, no obvious apoptotic changes were identified by flow cytometric analysis. However, the number of apoptotic cells was significantly increased following resveratrol treatment in a dose-dependent manner (Figs. 2B and 3). 
A

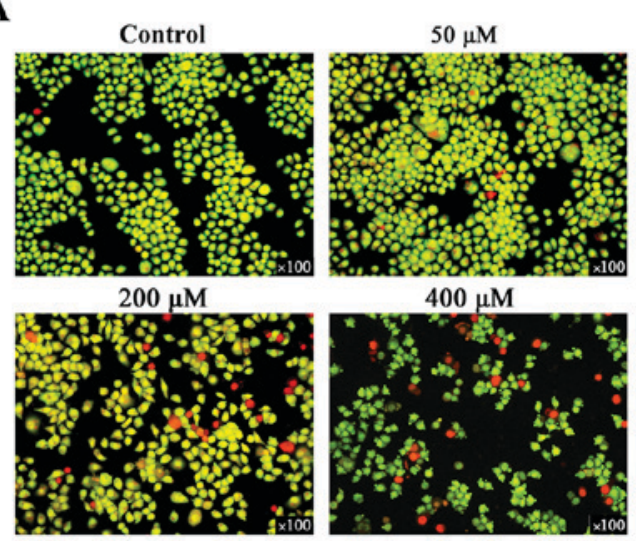

B

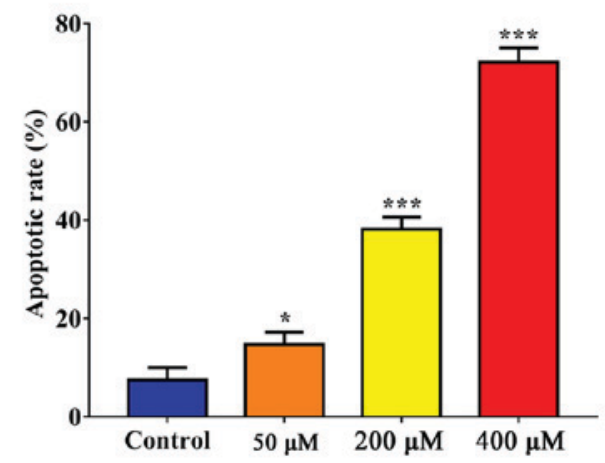

Figure 2. Resveratrol induces apoptosis in SGC-7901 cells. SGC-7901 cells were treated with 0, 50, 200 and $400 \mu \mathrm{M}$ resveratrol for 24 h. (A) The cells were stained with acridine orange/ethidium bromide and observed using a fluorescence microscope. (B) Quantification of results. Results are represented as the mean \pm standard deviation $(\mathrm{n}=3)$. ${ }^{*} \mathrm{P}<0.05$ and ${ }^{* * * *} \mathrm{P}<0.001$ vs. control group.

A
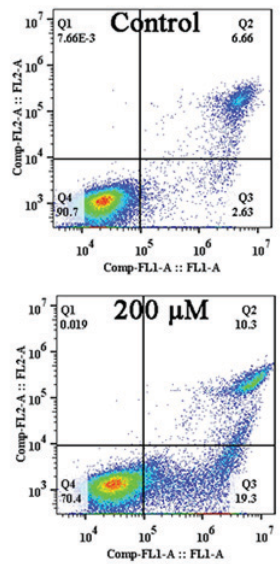
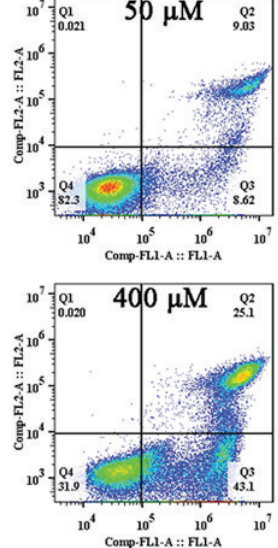

B

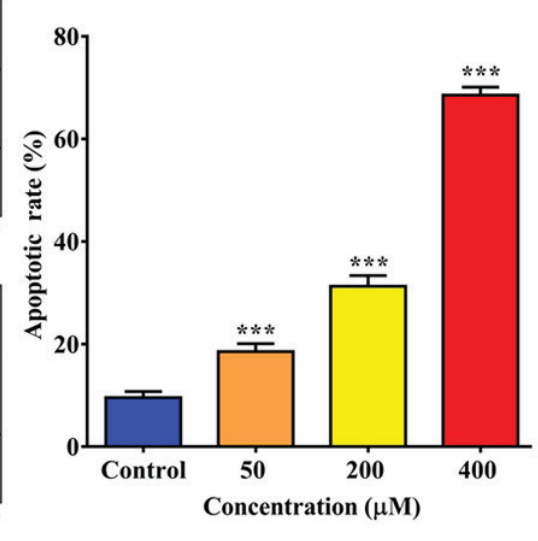

Figure 3. Resveratrol induces apoptosis in SGC-7901 cells. SGC-7901 cells were treated with 0, 50, 200 and $400 \mu \mathrm{M}$ resveratrol for 24 h. (A) The cells were stained with FITC-conjugated annexin V and PI for flow cytometric analysis. Flow cytometric profiles are presented with annexin V-FITC staining on the $\mathrm{x}$-axis and PI staining on the $\mathrm{y}$-axis. (B) Quantification of results. Results are presented as the mean \pm standard deviation ( $\mathrm{n}=3$ ). ${ }^{* * *} \mathrm{P}<0.001$ vs. control group. FITC, fluorescein isothiocyanate; PI, propidium iodide; Q, quadrant.

Resveratrol promotes S-phase arrest in SGC-7901 cells. Cell cycle distribution was observed by flow cytometric analysis. As presented in Fig. 4A, the proportion of cells in S-phase increased to $34.06 \%$ in the presence of resveratrol $(50 \mu \mathrm{M})$ compared with $26.08 \%$ in the control group $(\mathrm{P}<0.05)$. When treated with $200 \mu \mathrm{M}$ resveratrol, the proportion of SGC-7901 cells in S-phase was 59.29\%; however, the proportion of SGC-7901 cells in S-phase was 50.3\% when treated with $400 \mu \mathrm{M}$ resveratrol (Fig. 4).

Effect of resveratrol on $N F-\kappa B$ expression. The apoptosis-associated proteins Bax and Bcl-2, caspase- 3 and caspase- 8 were detected using western blotting. The results indicated that $200 \mu \mathrm{M}$ resveratrol induced significant upregulation of Bax and cleaved caspase- 3 compared with the control group, respectively ( $\mathrm{P}<0.001$; Figs. 5 and 6$)$. Additionally, Bcl-2 was significantly downregulated following treatment with $50 \mu \mathrm{M}$ resveratrol $(\mathrm{P}<0.01$; Fig, 5). As presented in Fig. 6 , SGC-7901 cells that were treated with $50 \mu \mathrm{M}$ resveratrol exhibited an increase in the expression of activated cleaved caspases compared with the control group. In addition, resveratrol treatment decreased the levels of pro-caspase-3 and pro-caspase-8. Following resveratrol treatment, the activation of caspase- 3 and caspase- 8 increased. These results suggested that resveratrol-induced cell death is associated with the death receptor pathway. In addition, western blot analysis was used to determine the levels of NF- $\kappa \mathrm{B}$ (p65) and phospho-NF- $\mathrm{kB}$ (p65) (Fig. 7A). The level of NF- $\kappa B$ (p65) expression was significantly decreased following treatment with $50 \mu \mathrm{M}$ resveratrol compared with the control $(\mathrm{P}<0.001$; Fig. 7B), which suggests that the inhibition of the NF- $\kappa \mathrm{B}$ signaling pathway was involved in resveratrol-induced apoptosis in SGC-7901 cells. As presented in Fig. 7B and D, phospho-NF- $\mathrm{kB}$ (p65) expression decreased in the cytoplasm and in the nucleus.

\section{Discussion}

The results of the present study indicated that resveratrol was able to significantly inhibit the viability and induce the apoptosis of SGC-7901 cells in a dose- and time-dependent manner 
A
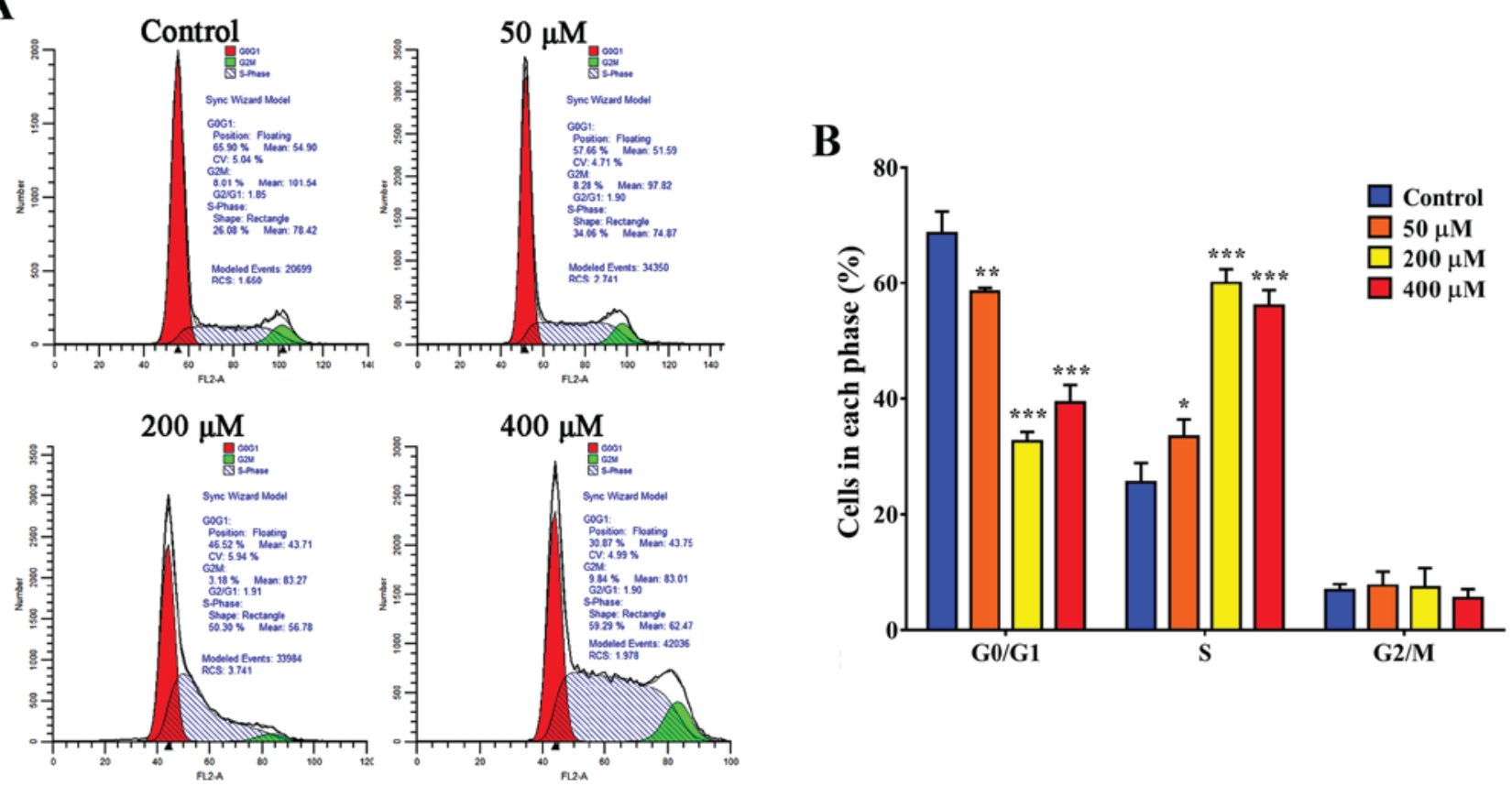

Figure 4. Flow cytometric analysis of cell cycle phase distribution in SGC-7901 cells. (A) SGC-7901 cells were treated with $0,50,200,400 \mu \mathrm{M}$ of resveratrol for $24 \mathrm{~h}$. Propidium iodide staining of SGC-7901 cells is presented. (B) Distribution of SGC-7901 cells among $\mathrm{G}_{0} / \mathrm{G}_{1-}, \mathrm{S}-$ and $\mathrm{G}_{2} / \mathrm{M}^{-p h a s e s}$. Results are presented as the mean \pm standard deviation $(\mathrm{n}=3) .{ }^{*} \mathrm{P}<0.05,{ }^{* *} \mathrm{P}<0.01$ and ${ }^{* * *} \mathrm{P}<0.001$ vs. control group.

A

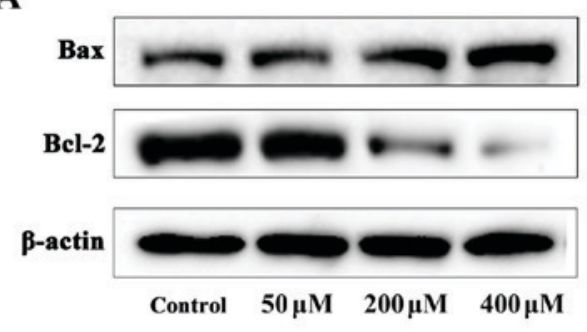

B

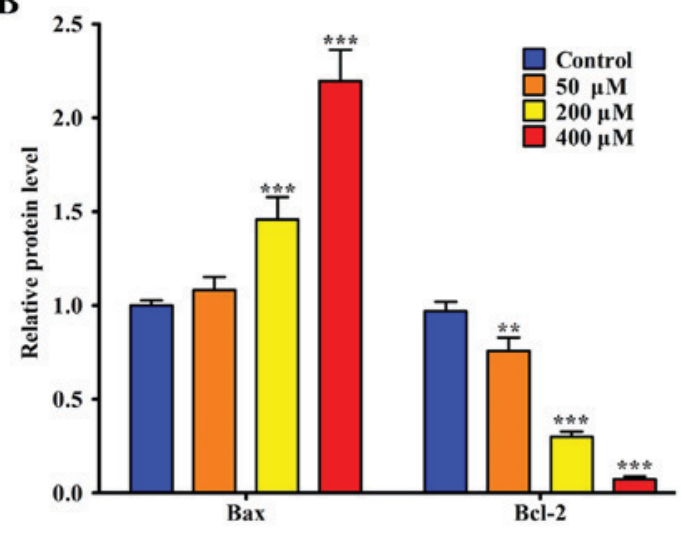

Figure 5. Western blot analysis of apoptotic-associated proteins: Bax and Bcl-2. SGC-7901 cells were treated with $0,50,200$ and $400 \mu \mathrm{M}$ resveratrol for $24 \mathrm{~h}$ and analyzed for protein expression. (A) Western blots of Bax and Bcl-2. (B) The levels of Bax and Bcl-2 proteins were quantified. Results are represented as the mean \pm standard deviation $(\mathrm{n}=3) .{ }^{* *} \mathrm{P}<0.01$ and ${ }^{* * *} \mathrm{P}<0.001$ vs. control group. Bcl-2, B-cell lymphoma 2; Bax, Bcl-2-associated $\mathrm{X}$ protein.

within a certain range, which is consistent with the results of a previous study on pancreatic cancer (23).

By analyzing the results of the MTT assay, it was identified that when the concentration of resveratrol was $\geq 50 \mu \mathrm{M}$ (except $200 \mu \mathrm{M}$ ), the inhibition rates of cell viability at $36 \mathrm{~h}$ were not significantly different from those at $48 \mathrm{~h}$ at the same concentration. Additionally, when the concentration of resveratrol was $\geq 200 \mu \mathrm{M}$, the inhibition rates of cell viability were not significantly different between 24 and $36 \mathrm{~h}$ at the same concentration. We hypothesize that, once the concentration had increased to a certain point, prolonging the duration of drug treatment did not make a difference to the inhibition of cell viability following resveratrol treatment.

Decreased cell viability is a comprehensive response, which reflects the functional state of cells in a number of aspects. Inhibition of cell proliferation, induction of apoptosis or autophagy, and cytotoxic necrosis all decrease cell viability. Yu et al (24) demonstrated that resveratrol decreases cell viability by way of the induction of apoptosis and $\mathrm{G}_{2} / \mathrm{M}$-phase cell cycle arrest. However, Opipari et al (25) identified that resveratrol induces cell death in ovarian cancer A2780 cells via a mechanism distinct from apoptosis. Neither apoptotic pathways associated with Bcl-2 and Bcl-xL nor activation of caspase- 9 were demonstrated to be required for the resveratrol-induced death of A2780 cells. Furthermore, decreased cell viability associated with the induction of autophagy was observed in breast cancer stem-like cells following treatment with resveratrol (17).

The cell cycle is a basic process common to all living organisms. The cell cycle can be divided into two major 
A

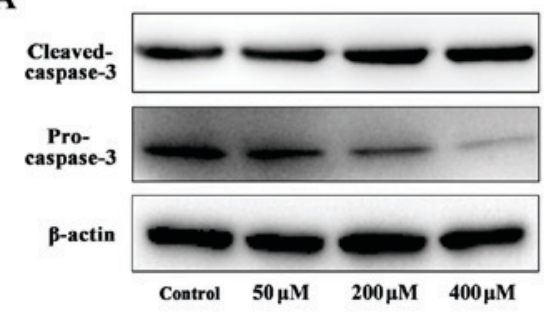

C

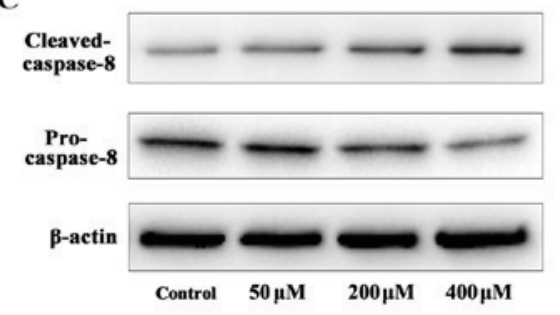

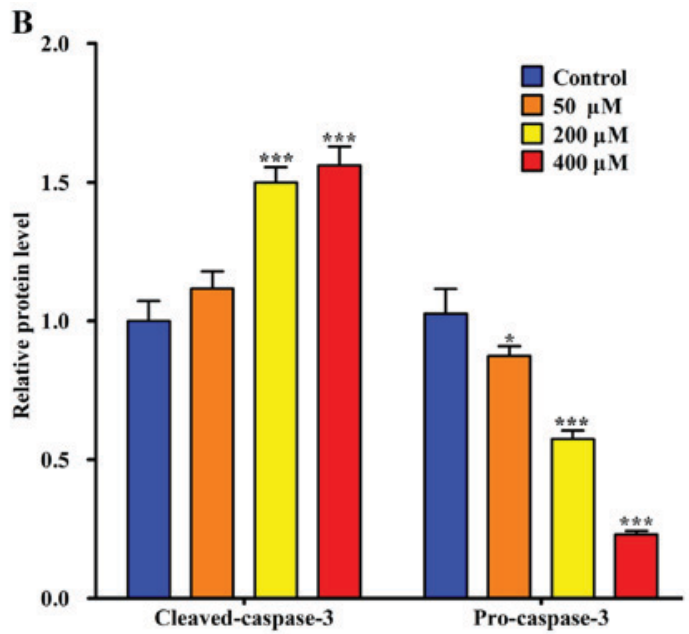

D

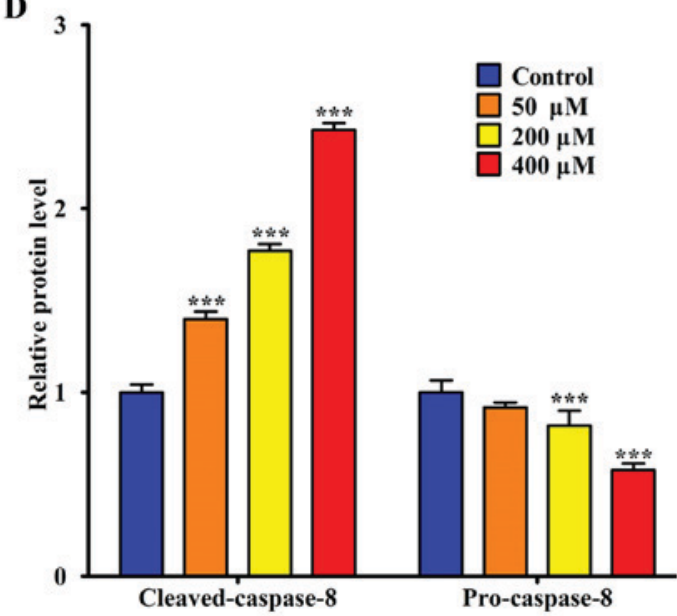

Figure 6. Western blot analysis of apoptosis-associated proteins caspase-3 and caspase-8. (A) Protein expression of cleaved caspase-3 and pro-caspase-3 determined by western blotting. (B) Quantification of cleaved caspase-3 and pro-caspase-3 protein levels. (C) Expression of cleaved caspase- 8 and pro-caspase- 8 proteins analyzed by western blotting. (D) Quantification of cleaved caspase- 8 and pro-caspase- 8 protein levels. Results are presented as the mean \pm standard deviation ( $n=3)$. ${ }^{*} \mathrm{P}<0.05$ and ${ }^{* * *} \mathrm{P}<0.001$ vs. control group.

phases: Mitosis phase (M-phase) and interphase. On the basis of DNA synthesis, interphase is divided into $\mathrm{G}_{1^{-}}, \mathrm{S}$ - and $\mathrm{G}_{2}$-phases. It has been identified that the effect of resveratrol on the cell cycle is primarily via two mechanisms: i) Decreasing the proportion of $\mathrm{G}_{0} / \mathrm{G}_{1}$-phase cells; and ii) blocking S-phase cells, namely the $\mathrm{G}_{1}-\mathrm{S}$ and $\mathrm{S}-\mathrm{G}_{2}$ transitions, thereby inhibiting tumor cell proliferation (26). In the present study, cell cycle assay indicated that resveratrol was able to arrest SGC-7901 cells at S-phase, suggesting that blocking S-phase cells may be associated with resveratrol-induced apoptosis in SGC-7901 cells.

Apoptosis, an efficient cell death program, is primarily mediated via the intrinsic or the extrinsic pathway in response to different stimuli in various cell types. Dysregulated apoptosis is a distinguishing feature of human cancer. The initiation and execution of endogenous and exogenous apoptosis are regulated by Bcl-2 and caspase family proteins $(27,28)$. It is well-known that $\mathrm{Bcl}-2$ is an anti-apoptotic protein, and $\mathrm{Bax}$ is a pro-apoptotic protein (29). The balance of these two types of protein has a key function in regulating the sensitivity of cells to apoptosis (30). In the present study, the results indicated that the $\mathrm{Bax} / \mathrm{Bcl}-2$ ratio increased with resveratrol treatment, which suggested that resveratrol may inhibit the proliferation of gastric cancer cells via downregulating anti-apoptotic proteins and upregulating pro-apoptotic proteins. Abnormal caspase expression and activation have been involved in various types of cancer $(31,32)$. In the present study, western blot analysis indicated that the levels of cleaved caspase-3 protein in SGC-7901 cells significantly increased following resveratrol treatment. By contrast, expression of pro-caspase- 3 and pro-caspase- 8 was markedly decreased in the experimental groups following resveratrol treatment. Furthermore, this resulted in a higher ratio of cleaved caspase-3/pro-caspase-3 (8). Therefore, increased caspase-3 and caspase- 8 activation in the presence of resveratrol may contribute to resveratrol-induced apoptosis of SGC-7901 cells.

The NF- $\mathrm{kB}$ family of transcription factors is known for its function in immunity and inflammation (33), and its abnormal upregulation has been observed in a number of types of cancer (34-37). In the present study, the expression of NF- $\mathrm{KB}$ was negatively associated with the viability and survival of SGC-7901 cells. The presence of an NF-kB-binding site in the $\mathrm{Bcl}-2$ promoter has been identified. Transactivation of transcription by NF- $\mathrm{KB}$ from the $\mathrm{Bcl}-2 \mathrm{p} 2$ promoter is mediated via the Bcl-2 p2 site 1 (38). In certain cancer cell lines, the activation of NF- $\mathrm{kB}$ is triggered by chemotherapeutic drugs and ionizing 
A

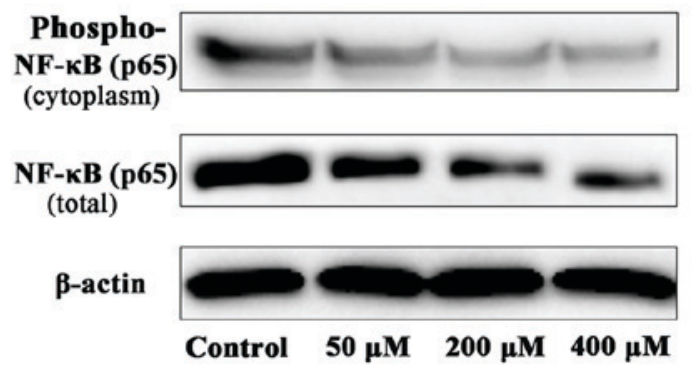

C

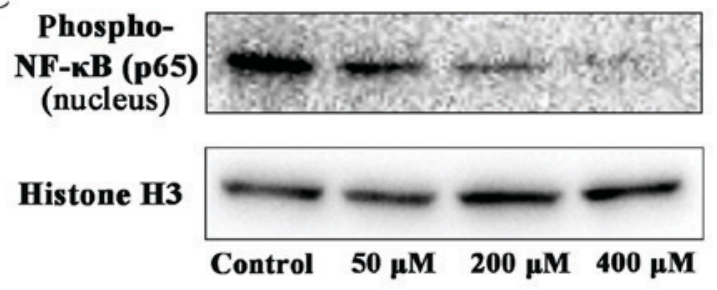

B

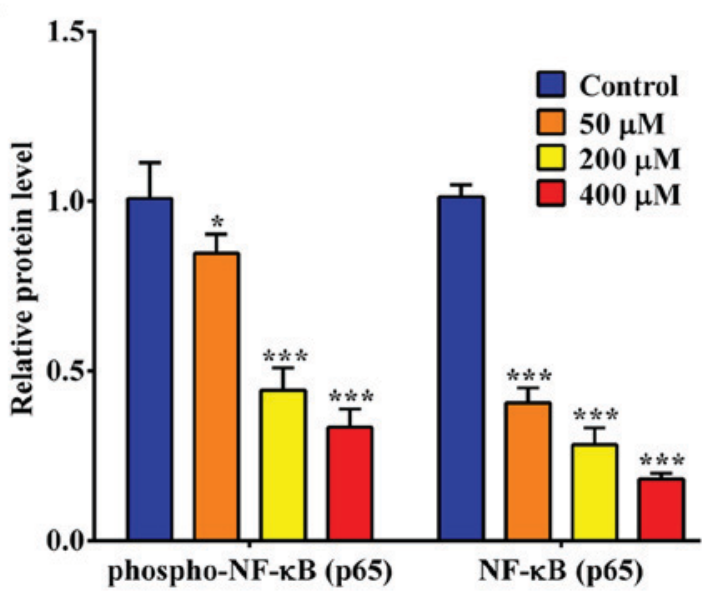

D

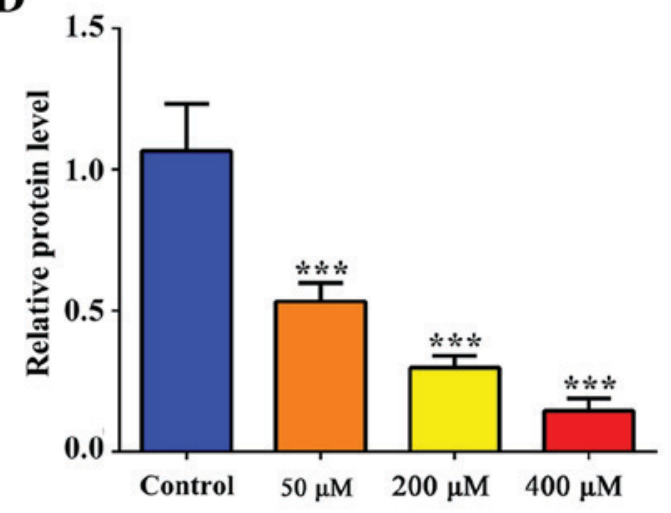

Figure 7. Expression of the apoptotic-associated proteins and NF- $\kappa \mathrm{B}$ proteins as assessed by western blotting. (A) Western blots of total NF- $\kappa \mathrm{B}$ (p65)

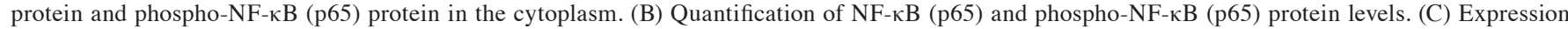
of phospho-NF- $\kappa \mathrm{B}$ (p65) protein determined by western blotting. (D) Quantification of phospho-NF- $\mathrm{B}$ (p65) protein levels. Results are presented as the mean \pm standard deviation $(n=3)$. ${ }^{*} \mathrm{P}<0.05$ and ${ }^{* * * *} \mathrm{P}<0.001$ vs. control group. $\mathrm{NF}-\kappa \mathrm{B}$, nuclear factor $\kappa \mathrm{B}$.

radiation that accompany the activation of the Bcl-2 family of proteins (39). Sun et al (40) identified that resveratrol treatment was able to arrest cells at $\mathrm{G}_{1}$ - and $\mathrm{S}$-phases. NF- $\mathrm{KB}$ was also downregulated, which resulted in decreased expression of anti-apoptotic proteins, including Bcl-2, Bcl-2-like protein 1 and X-linked inhibitor of apoptosis. In myeloma, caspase-3 activation and loss of mitochondrial transmembrane potential were observed to be associated with resveratrol-induced apoptosis (41). In line with these results, it is possible that NF- $\kappa \mathrm{B}$ has a key function in resveratrol-induced apoptosis in SGC-7901 cells. In the present study, resveratrol was able to downregulate the expression and activation of $\mathrm{NF}-\kappa \mathrm{B}$ in cancer cells, which regulated the expression of apoptotic-associated proteins and also modulated cell cycle distribution.

In conclusion, the results of the present study indicated that resveratrol was able to inhibit the viability and induce the apoptosis of SGC-7901 cancer cells by inhibiting NF- $\mathrm{B}$ activation. Therefore, a potential application of resveratrol may be as an anticancer drug for the treatment of gastric cancer.

\section{Acknowledgements}

The authors thank Dr Zhigang Wang and Dr Jianghuan Hua (School of Basic Medical Sciences, Hubei University of
Chinese Medicine, Wuhan, China), for assisting in the editing of the manuscript before submission.

\section{Funding}

The present study was supported by the Nature Science Foundation of Hubei Province, China (grant nos. 2013CFB067 and 2013CFB068).

\section{Availability of data and materials}

All data generated or analyzed during this study are included in this published article.

\section{Authors' contributions}

QFY, GZ and XXW conceived and designed the study. XXW, QL, YDX and BRZ performed the experiments. XXW and GZ wrote the paper. GZ, QFY, XXW, YDX, BRZ and QL reviewed and edited the paper. All authors read and approved the paper.

\section{Ethics approval and consent to participate}

Not applicable. 


\section{Patient consent for publication}

Not applicable.

\section{Competing interests}

The authors declare that they have no competing interests.

\section{References}

1. Kamangar F, Dores GM and Anderson WF: Patterns of cancer incidence, mortality, and prevalence across five continents: Defining priorities to reduce cancer disparities in different geographic regions of the world. J Clin Oncol 24: 2137-2150, 2006.

2. Cunningham SC, Kamangar F, Kim MP, Hammoud S, Haque R, Maitra A, Montgomery E, Heitmiller RE, Choti MA, Lillemoe KD, et al: Survival after gastric adenocarcinoma resection: Eighteen-year experience at a single institution. J Gastrointest Surg 9: 718-725, 2005.

3. Stewart B and Wild CP (eds): World Cancer Report 2014. Health, 2017.

4. Orditura M, Galizia G, Sforza V, Gambardella V, Fabozzi A, Laterza MM, Andreozzi F, Ventriglia J, Savastano B, Mabilia A, et al: Treatment of gastric cancer. World J Gastroenterol 20: 1635-1649, 2014.

5. Nobili S, Lippi D, Witort E, Donnini M, Bausi L, Mini E and Capaccioli S: Natural compounds for cancer treatment and prevention. Pharmacol Res 59: 365-378, 2009.

6. Florea AM and Büsselberg D: Cisplatin as an anti-tumor drug: Cellular mechanisms of activity, drug resistance and induced side effects. Cancers (Basel) 3: 1351-1371, 2011.

7. Wu Q, Yang Z, Nie Y, Shi Y and Fan D: Multi-drug resistance in cancer chemotherapeutics: Mechanisms and lab approaches. Cancer Lett 347: 159-166, 2014.

8. James MI, Iwuji C, Irving G, Karmokar A, Higgins JA, Griffin-Teal N, Thomas A, Greaves P, Cai H, Patel SR, et al: Curcumin inhibits cancer stem cell phenotypes in ex vivo models of colorectal liver metastases, and is clinically safe and tolerable in combination with FOLFOX chemotherapy. Cancer Lett 364: $135-141,2015$.

9. He B, Wei W, Liu J, Xu Y and Zhao G: Synergistic anticancer effect of curcumin and chemotherapy regimen FP in human gastric cancer MGC-803 cells. Oncol Lett 14: 3387-3394, 2017.

10. Tran KQ, Tin AS and Firestone GL: Artemisinin triggers a G1 cell cycle arrest of human Ishikawa endometrial cancer cells and inhibits Cyclin Dependent Kinase-4 promoter activity and expression by disrupting NF-kB transcriptional signaling. Anticancer Drugs 25: 270-281, 2014.

11. Novelle MG, Wahl D, Diéguez C, Bernier M and de Cabo R: Resveratrol supplementation: Where are we now and where should we go? Ageing Res Rev 21: 1-15, 2015.

12. Baur JA and Sinclair DA: Therapeutic potential of resveratrol: The in vivo evidence. Nat Rev Drug Discov 5: 493-506, 2006.

13. Du RH, Dai T, Cao WJ, Lu M,Ding JH and Hu G: Kir6.2-containing ATP-sensitive $\mathrm{K}(+)$ channel is required for cardioprotection of resveratrol in mice. Cardiovasc Diabetol 13: 35, 2014.

14. Inglés M, Gambini J, Miguel MG, Bonet-Costa V, Abdelaziz KM, El Alami M, Viña J and Borrás C: PTEN mediates the antioxidant effect of resveratrol at nutritionally relevant concentrations. Biomed Res Int 2014: 580852, 2014.

15. Labinskyy N, Csiszar A, Veress G, Stef G, Pacher P, Oroszi G, Wu J and Ungvari Z: Vascular dysfunction in aging: Potential effects of resveratrol, an anti-inflammatory phytoestrogen. Curr Med Chem 13: 989-996, 2006.

16. Valenzano DR, Terzibasi E, Genade T, Cattaneo A, Domenici L and Cellerino A: Resveratrol prolongs lifespan and retards the onset of age-related markers in a short-lived vertebrate. Curr Biol 16: 296-300, 2006.

17. Fu Y, Chang H, Peng X, Bai Q, Yi L, Zhou Y, Zhu J and Mi M: Resveratrol inhibits breast cancer stem-like cells and induces autophagy via suppressing $\mathrm{Wnt} / \beta$-catenin signaling pathway. PLoS One 9: e102535, 2014

18. Yuan SL, Wei YQ, Wang XJ, Xiao F, Li SF and Zhang J: Growth inhibition and apoptosis induction of tanshinone II-A on human hepatocellular carcinoma cells. World J Gastroenterol 10 2024-2028, 2004.
19. Arora S, Jain J, Rajwade J and Paknikar K: Interactions of silver nanoparticles with primary mouse fibroblasts and liver cells. Toxicol Appl Pharmacol 236: 310-318, 2009.

20. Chen X, Zhao G, Wang F, Gao F, Luo H, Wang Y, Du Y, Chen X, Xue C, Dong Z and Song G: Upregulation of miR-513b inhibits cell proliferation, migration, and promotes apoptosis by targeting high mobility group-box 3 protein in gastric cancer. Tumor Biol 35: 11081-11089, 2014.

21. Guo H, Xu YM, Ye ZQ, Yu JH and Hu XY: Curcumin induces cell cycle arrest and apoptosis of prostate cancer cells by regulating the expression of IkappaBalpha, c-Jun and androgen receptor. Pharmazie 68: 431-434, 2013.

22. Zhu P, Zhang J, Zhu J, Shi J, Zhu Q and Gao Y: MiR-429 induces gastric carcinoma cell apoptosis through Bcl-2. Cell Physiol Biochem 37: 1572-1580, 2015.

23. Ding XZ and Adrian TE: Resveratrol inhibits proliferation and induces apoptosis in human pancreatic cancer cells. Pancreas 25: e71-e76, 2002.

24. Yu XD, Yang JL, Zhang WL and Liu DX: Resveratrol inhibits oral squamous cell carcinoma through induction of apoptosis and G2/M phase cell cycle arrest. Tumour Biol 37: 2871-2877, 2016.

25. Opipari AW Jr, Tan L, Boitano AE, Sorenson DR, Aurora A and Liu JR: Resveratrol-induced autophagocytosis in ovarian cancer cells. Cancer Res 64: 696-703, 2004

26. Kim AL, Zhu Y, Zhu H, Han L, Kopelovich L, Bickers DR and Athar M: Resveratrol inhibits proliferation of human epidermoid carcinoma A431 cells by modulating MEK1 and AP-1 signalling pathways. Exp Dermatol 15: 538-546, 2006.

27. Danial NN and Korsmeyer SJ: Cell death: Critical control points. Cell 116: 205-219, 2004.

28. Galluzzi L, Vitale I, Abrams JM, Alnemri ES, Baehrecke EH, Blagosklonny MV, Dawson TM, Dawson VL, El-Deiry WS, Fulda S, et al: Molecular definitions of cell death subroutines: Recommendations of the nomenclature committee on cell death 2012. Cell Death Differ 19: 107-120, 2012.

29. Phillips TM, McBride WH and Pajonk F: The response of CD24(-/low/CD44+ breast cancer-initiating cells to radiation. J Natl Cancer Inst 98: 1777-1785, 2006.

30. Tsujimoto Y: Role of $\mathrm{Bcl}-2$ family proteins in apoptosis: Apoptosomes or mitochondria? Genes to cells 3: 697-707, 1998.

31. Estrov Z, Thall PF, Talpaz M, Estey EH, Kantarjian HM, Andreeff M, Harris D, Van Q, Walterscheid M and Kornblau SM: Caspase 2 and caspase 3 protein levels as predictors of survival in acute myelogenous leukemia. Blood 92: 3090-3097, 1998.

32. Hopkins-Donaldson S, Bodmer JL, Bourloud KB, Brognara CB, Tschopp J and Gross N: Loss of caspase-8 expression in highly malignant human neuroblastoma cells correlates with resistance to tumor necrosis factor-related apoptosis-inducing ligand-induced apoptosis. Cancer Res 60: 4315-4319, 2000.

33. Karin M and Greten FR: NF-kappaB: Linking inflammation and immunity to cancer development and progression. Nat Rev Immunol 5: 749-759, 2005.

34. Gasparini C, Celeghini C, Monasta L and Zauli G: NF- $\kappa$ B pathways in hematological malignancies. Cell Mol Life Sc 71: 2083-2102,2014.

35. Pacifico F and Leonardi A: NF-kappaB in solid tumors. Biochem Pharmacol 72: 1142-1152, 2006.

36. Karin M: Nuclear factor-kappaB in cancer development and progression. Nature 441: 431-436, 2006.

37. Liu B, Sun L, Liu Q, Gong C, Yao Y, Lv X, Lin L, Yao H, Su F, $\mathrm{Li}$, et al: A Cytoplasmic NF- $\mathrm{kB}$ interacting long noncoding RNA Blocks IкB Phosphorylation and suppresses breast cancer metastasis. Cancer Cell 27: 370-381, 2015.

38. Catz SD and Johnson JL: Transcriptional regulation of bcl-2 by nuclear factor kappa B and its significance in prostate cancer. Oncogene 20: 7342-7351, 2001.

39. Li F and Sethi G: Targeting transcription factor NF-kappaB to overcome chemoresistance and radioresistance in cancer therapy. Biochim Biophys Acta 1805: 167-180, 2010.

40. Sun C, Hu Y, Liu X, Wu T, Wang Y, He W and Wei W: Resveratrol downregulates the constitutional activation of nuclear factor-kappaB in multiple myeloma cells, leading to suppression of proliferation and invasion, arrest of cell cycle, and induction of apoptosis. Cancer Genet Cytogenet 165: 9-19, 2006.

41. Shimizu T,Nakazato T, Xian MJ, Sagawa M, Ikeda Y and Kizaki M: Resveratrol induces apoptosis of human malignant B cells by activation of caspase- 3 and p38 MAP kinase pathways. Biochem Pharmacol 71: 742-750, 2006.

This work is licensed under a Creative Commons Attribution-NonCommercial-NoDerivatives 4.0 International (CC BY-NC-ND 4.0) License. 